\title{
Efficacy of phage cocktail AB-SA01 therapy in diabetic mouse wound infections caused by multidrug-resistant Staphylococcus aureus
}

Legesse Garedew Kifelew ${ }^{1,2^{*}}$ (D, Morgyn S. Warner ${ }^{3,4}$, Sandra Morales ${ }^{5}$, Lewis Vaughan ${ }^{6}$, Richard Woodman ${ }^{7}$, Robert Fitridge ${ }^{8}$, James G. Mitchell ${ }^{1}$ and Peter Speck ${ }^{1}$

\begin{abstract}
Background: Diabetic foot ulcer (DFU) is a serious complication of diabetes mellitus. Antibiotic-resistant Staphylococcus aureus is frequently isolated from DFU infections. Bacteriophages (phages) represent an alternative or adjunct treatment to antibiotic therapy. Here we describe the efficacy of AB-SA01, a cocktail of three S. aureus Myoviridae phages, made to current good manufacturing practice (CGMP) standards, and which has undergone two phase I clinical trials, in treatment of multidrug-resistant (MDR) S. aureus infections.

Results: Wounds of saline-treated mice showed no healing, but expanded and became inflamed, ulcerated, and suppurating. In contrast, AB-SA01 treatment decreased the bacterial load with efficacy similar or superior to vancomycin treatment. At the end of the treatment period, there was a significant decrease $(p<0.001)$ in bacterial load and wound size in infected phage- and vancomycin-treated groups compared with infected saline-treated mice. In phage-treated mice, wound healing was seen similar to vancomycin treatment. No mortality was recorded associated with infections, and post-mortem examinations did not show any evident pathological lesions other than the skin wounds. No adverse effects related to the application of phages were observed.

Conclusion: Topical application of phage cocktail AB-SA01 is effective, as shown by bacterial load reduction and wound closure, in the treatment of diabetic wound infections caused by MDR S. aureus. Our results suggest that topical phage cocktail treatment may be effective in treating antibiotic-resistant S. aureus DFU infections.
\end{abstract}

Keywords: Diabetic mice, Infection, MDR S. aureus, Phage cocktail, Treatment, Wound

\section{Background}

Complications of diabetes, such as diabetic foot ulcers (DFUs), are common, multifactorial in origin, and costly [1]. The global burden of DFUs is rising, affecting up to 26.1 million people each year [2]. DFUs are the precipitating cause for nearly $90 \%$ of limb amputations among

\footnotetext{
* Correspondence: legesse.kifelew@flinders.edu.au

${ }^{1}$ College of Science and Engineering, Flinders University, Adelaide, South Australia, Australia

${ }^{2}$ St Paul's Hospital Millennium Medical College, Addis Ababa, Ethiopia Full list of author information is available at the end of the article
}

persons with diabetes [3]. Worldwide, $6.3 \%$ of persons living with diabetes are affected by DFUs, and the lifetime incidence of a foot ulcer among persons with diabetes is estimated between 19 and 34\% [2]. The 5-year mortality rate following foot amputation due to DFUs has been estimated at up to $74 \%$ [4]. DFU management is costly because it may involve imaging studies, revascularization, wound dressing for lengthy periods, debridement, antibiotic therapy, and management of metabolic abnormalities $[5,6]$. In the USA, the annual cost of DFU

(c) The Author(s). 2020 Open Access This article is licensed under a Creative Commons Attribution 4.0 International License, which permits use, sharing, adaptation, distribution and reproduction in any medium or format, as long as you give appropriate credit to the original author(s) and the source, provide a link to the Creative Commons licence, and indicate if changes were made. The images or other third party material in this article are included in the article's Creative Commons licence, unless indicated otherwise in a credit line to the material. If material is not included in the article's Creative Commons licence and your intended use is not permitted by statutory regulation or exceeds the permitted use, you will need to obtain permission directly from the copyright holder. To view a copy of this licence, visit http://creativecommons.org/licenses/by/4.0/ The Creative Commons Public Domain Dedication waiver (http://creativecommons.org/publicdomain/zero/1.0/) applies to the data made available in this article, unless otherwise stated in a credit line to the data. 
management is estimated at an additional \$9-13 billion over the cost of diabetes itself [7]. In England, it is estimated that the annual cost of managing DFUs exceeds the total cost of breast, prostate, and lung cancers combined [8].

$S$. aureus is a virulent pathogen frequently isolated from DFU $[5,9,10]$. A study in Australia found that two-thirds of DFU patients were infected with S. aureus, and nearly half were methicillin-resistant (MRSA), for which there are limited antimicrobial treatment options [11]. Hence, antibiotic resistance is a major obstacle in treating infections caused by this pathogen $[5,12]$. Bacteriophages (phages, viruses that infect bacteria) represent an alternative or adjunct therapy to antibiotics. Lytic phages kill their bacterial host by lysis (bursting the infected bacterial cell to release progeny phages) [13]. Before the advent of antibiotics in the 1940s, phages were widely used in the USA and Europe. However, following the success of antibiotics, phage treatment was excluded from Western medicine, while it has continued to be practiced in Eastern Europe for $>100$ years to treat bacterial infections [14]. The process of phage infection and subsequent self-replication in bacteria offers advantages over antibiotics: phages amplify themselves at the infection site provided there are sensitive bacterial hosts [15]. Phages are specific for the bacterial species they infect, an advantage over broadly active antimicrobials, as phages are not expected to disrupt a patients' normal microflora [16, 17]. Phages lyse biofilm structures of bacteria, such as those typically found in infected DFUs $[15,18]$.

There is much evidence that phage use is safe (reviews: $[19,20])$, and its extensive Russian and Georgian use has few adverse event reports [19]. Phages only infect bacteria, and are the most common biological entities in the biosphere and human body [21]. In 2006, the US Food and Drug Administration (FDA) gave "Generally Regarded As Safe" (GRAS) status to phage product Listex, against Listeria monocytogenes so that it can be added to human foods as a processing aid [22]; many phage products in this industry now have such status.

The physician from Phagebiotics Research Foundation used Eliava Institute, Republic of Georgia, S. aureus phage Sb-1, to successfully treat five patients with DFU infections that were unresponsive to standard antibiotics and which left the patients facing potential amputations. In each case, full wound closure was achieved, and the toes were saved [23]. Further studies with a product that meets cGMP regulations would support the uptake of this treatment to broader Western medicine. We used a cocktail of three phages that are related to Staphylococcus phage $\mathrm{K}$, designated AB-SA01 [24], which has undergone two phase I clinical trials and is made to cGMP standard. A previous study confirmed that AB-SA01 showed no or minimum off-target effects [24]. The objective of this work was to determine the efficacy of this cGMP phage product in treating $S$. aureus infection in a mouse model in which diabetes is induced by administration of the naturally occurring antineoplastic agent streptozotocin. Here we report the efficacy of this phage preparation in treating MDR (resistant to benzylpenicillin, oxacillin, ciprofloxacin, erythromycin, and clindamycin) S. aureus infected deep skin wounds in diabetic mice.

\section{Results}

\section{Confirmation of diabetic mouse infection model}

Female Balb/c mice rendered diabetic by intraperitoneal (IP) injection of streptozotocin (STZ) were used in this study. Most of the diabetic mice manifested sustained hyperglycaemia and continued weight loss in the first 2 weeks post-STZ injection. Subjective observation of cage litter showed increased urine production requiring daily rather than every 3rd day litter changes, consistent with polyuria. Additionally, water intake by diabetic mice was estimated to be double their pre-STZ injection intake, indicative of polydipsia.

Forty (83.3\%) mice developed diabetes with nonfasting blood glucose level $(\mathrm{BGL}) \geq 13.9 \mathrm{mmol} / \mathrm{L}$ within the first 2 weeks of post-STZ administration. Of the remaining mice, 3 (6.3\%) failed to develop diabetes, and $5(10.4 \%)$ died before their diabetes status was determined. Of the diabetic mice, 21 (52.5\%) developed severe hyperglycaemia. While the mean body weight of mice before STZ administration was $18.9 \pm 0 \mathrm{~g}$, the mean body weight of normal glycaemic, moderately hyperglycaemic, and severely hyperglycaemic mice groups were $19.3 \pm$ $1.0,17.8 \pm 1.4$, and $16.7 \pm 1.4 \mathrm{~g}$, respectively, at the end of the diabetes maintenance period. Neither body weight gain nor BGL decrease differed significantly between moderately and severely hyperglycaemic groups in the insulin treatment period $(\mathrm{p}>0.05)$.

Prior to the commencement of the wound infection treatment study, mice that failed to maintain body weight were euthanized $(n=7)$. Diabetic mice then were inoculated with $6.7 \log _{10}$ (CFU) MDR S. aureus SA632498 or $50 \mu \mathrm{l}$ of saline directly to the bilateral splinted excisional wounds on the dorsum, overlaid with gauze, and covered with Opsite. MDR S. aureus SA63-2498 was susceptible to vancomycin and phage cocktail ABSA01 and its components. Gauze patches $(10 \times 10 \mathrm{~mm})$ soaked with $70 \mu \mathrm{l}$ AB-SA01, equivalent to $7.9 \log 10 \mathrm{PFU}$, or $70 \mu \mathrm{l}$ saline solutions for the control group were applied every other day for 3 days starting from the day 3 of infection. Vancomycin-treated mice received $150 \mathrm{mg} /$ $\mathrm{kg}$ vancomycin IP twice daily for five consecutive days. No mortality was recorded associated with infections, 
and post-mortem examinations did not show any evident pathological lesions other than the skin wounds.

\section{Efficacy of AB-SA01 on bacterial load in diabetic mouse wound infections}

All infected wounds $($ no $=42)$ of the 21 mice yielded $S$. aureus, MDR SA63-2498, and the mean bacterial cell count ranged from 7.0-9.0 $\log _{10}(\mathrm{CFU} / \mathrm{swab})$ with median $8.1 \log _{10}(\mathrm{CFU} / \mathrm{swab})$. The mean bacterial cell count on day 3 of infection from swab samples was $8.1 \log _{10}$ (CFU/swab). The bacteria count on days 5, 7 and 10 of infection showed a significant decrease in all phage- and vancomycin-treated mice, as shown in Fig. 1.

No S. aureus was detected from more than half $(n=5 /$ 8) of phage-treated wounds, and the mean bacterial load from this group was $1.1 \log _{10}(\mathrm{CFU} / \mathrm{swab})$ on day 10 of the infection period with the maximum detection $4.3 \log _{10}$ (CFU/swab). In contrast, minimum $3.9 \log _{10}$ (CFU/swab) and mean $4.8 \log _{10}$ (CFU/swab) S. aureus cells were detected in vancomycin-treated mice on day 7 and at the end of the experiment, respectively, as shown in Table 1.

A statistically significant $(p<0.001)$ bacterial load decrease was observed on day 5 of infection for the infected phage-treated group. The vancomycin-treated mice showed a statistically significant $(p<0.05)$ bacterial load reduction on day 5 , and a more pronounced reduction $(p<0.001)$ was observed on day 7 of infection. On day 10 of infection, the bacterial load reduction due to phage cocktail treatment was statistically significantly $(p<0.05)$ less than vancomycin treatment. There was no
S. aureus detected from uninfected phage-treated mice wounds throughout the experimental period.

\section{Wound healing}

Infected phage- and vancomycin-treated mice showed a decrease in wound size during and after the course of treatment, leading to complete wound healing. All uninfected phage-treated wounds also decreased in size and had complete healing. In contrast, infected saline-treated wounds increased in size, as shown in Fig. 2.

The mean wound diameter at the end of the experiment was $0.0,0.2(0.0-1.5), 0.3(0.0-1.3)$, and 7.8 (6.19.0) $\mathrm{mm}$ for infected vancomycin-, infected phage-, uninfected phage-, and infected saline-treated groups, respectively. All infected saline-treated wounds manifested non-healing ulcers characterised by purulent exudate, discoloured granulation tissue, and foul odour. Compared to the infected saline-treated mice wound size, we found a significant $(p<0.05)$ wound size decreased on days 5, 7, and 10 of infection for infected phage-treated mice, as illustrated in Fig. 3.

There was a significant decrease $(p<0.001)$ in wound size in uninfected phage-, and infected phage-, and infected vancomycin-treated groups compared with infected saline-treated mice. There was no statistically significant difference $(p>0.05)$ in wound healing progression among uninfected phage-, infected phage-, and infected vancomycin-treated groups. Gross examination of the healed wounds showed no differences between these three treatment groups. Phage treatment caused

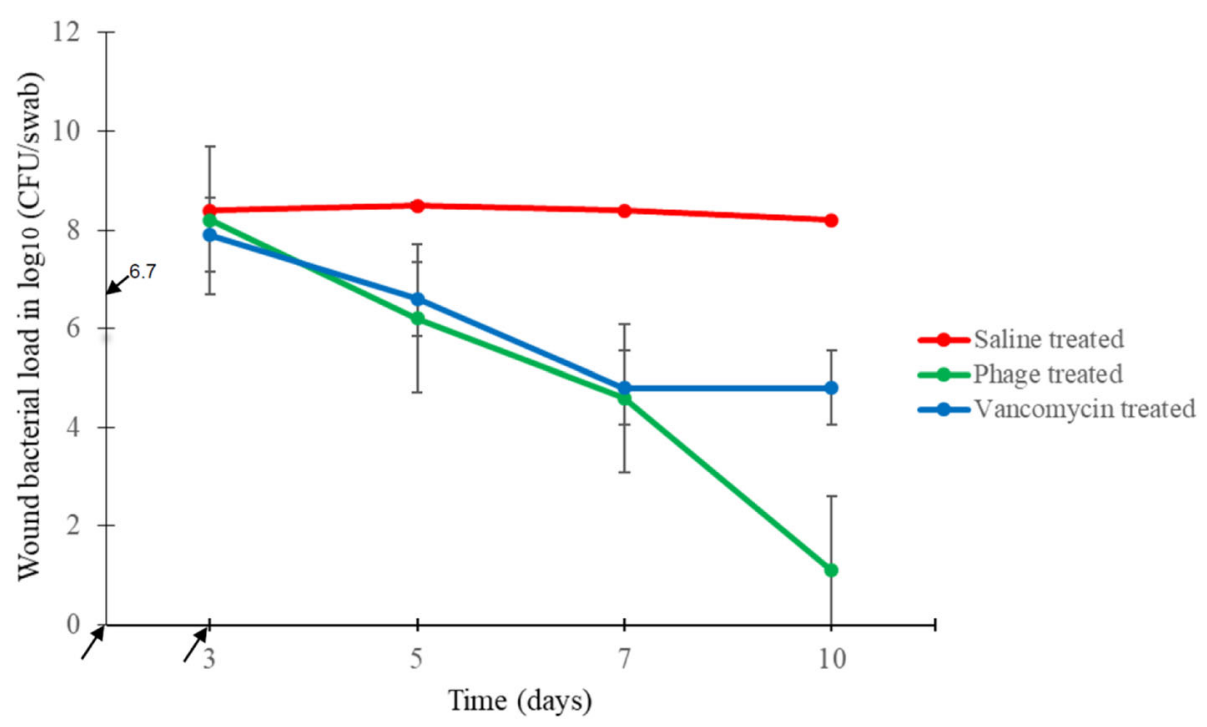

Fig. 1 Effect of phage treatment on S. aureus bacterial load compared to control and IP vancomycin treatment. Saline-treated mice (control, red); AB-SA01 phage-treated mice (green); vancomycin-treated mice (blue). No S. aureus was detected from uninfected phage-treated mice. The arrows on the horizontal axis indicate the infection date (first arrow, day 0) and treatment start date (second arrow, day 3), respectively. Treatments were applied from day 3 to day 7 of infection, as detailed in the text. The arrow on the vertical axis indicates the infection dose 
Table 1 Bacterial load ( $\log _{10}$ CFU/swab) after treatments in diabetic mice wounds infected with MDR S. aureus

\begin{tabular}{|c|c|c|c|c|c|c|}
\hline \multirow[t]{2}{*}{ Mouse ID } & \multirow[t]{2}{*}{$\begin{array}{l}\text { Treatment } \\
\text { group }\end{array}$} & \multicolumn{5}{|c|}{ Infection period } \\
\hline & & Day 0 & Day 3 & Day 5 & Day 7 & Day 10 \\
\hline 4-NEM & Saline & 0 & 8.99 & 8.36 & 8.51 & 8.57 \\
\hline 4-1 L & & 0 & 7.72 & 8.11 & 8.43 & 7.91 \\
\hline $4-2 R$ & & 0 & 8.34 & 8.85 & 8.38 & 8.18 \\
\hline 5-NEM & & 0 & 7.00 & 8.34 & 8.41 & 7.62 \\
\hline 5-1 L & & 0 & 8.76 & 8.70 & 8.20 & 8.11 \\
\hline $5-2 R$ & & 0 & 6.97 & 7.73 & 8.51 & 8.53 \\
\hline 10-RL & & 0 & 7.00 & 8.38 & 8.26 & 7.95 \\
\hline Mean \pm err & & 0 & $8.42 \pm 0.9$ & $8.47 \pm 0.4$ & $8.39 \pm 0.1$ & $8.23 \pm 0.3$ \\
\hline $7-1 R$ & Phage & 0 & 8.40 & 6.43 & 2.26 & 0.00 \\
\hline 7-1 L & & 0 & 8.40 & 6.18 & 5.72 & 2.00 \\
\hline 7-RL & & 0 & 7.88 & 6.45 & 6.30 & 2.28 \\
\hline $7-2 R$ & & 0 & 8.56 & 6.26 & 6.63 & 0.00 \\
\hline 9-NEM & & 1.1 & 8.38 & 6.28 & 2.48 & 4.34 \\
\hline $9-1 R$ & & 1.5 & 8.81 & 6.45 & 5.15 & 0.00 \\
\hline 9-1 L & & 0 & 8.41 & 5.80 & 5.72 & 0.00 \\
\hline 9-RL & & 0 & 6.66 & 5.43 & 2.32 & 0.00 \\
\hline Mean \pm err & & 0.3 & $8.19 \pm 0.7$ & $6.16 \pm 0.4$ & $4.57 \pm 1.9$ & $1.08 \pm 1.6$ \\
\hline $6-1 R$ & Vancomycin & 0 & 8.64 & 6.18 & 5.15 & 7.04 \\
\hline $6-R L$ & & 0 & 7.46 & 4.70 & 3.96 & 5.86 \\
\hline $6-2 R$ & & 0 & 8.04 & 7.99 & 4.75 & 6.75 \\
\hline 8-NEM & & 0 & 7.84 & 6.49 & 5.58 & 1.04 \\
\hline 8-1 L & & 0 & 7.80 & 6.52 & 4.28 & 6.04 \\
\hline $8-2 R$ & & 0 & 7.72 & 7.92 & 4.96 & 2.11 \\
\hline Mean \pm err & & 0 & $7.92 \pm 0.4$ & $6.63 \pm 1.2$ & $4.78 \pm 0.6$ & $4.81 \pm 2.6$ \\
\hline
\end{tabular}

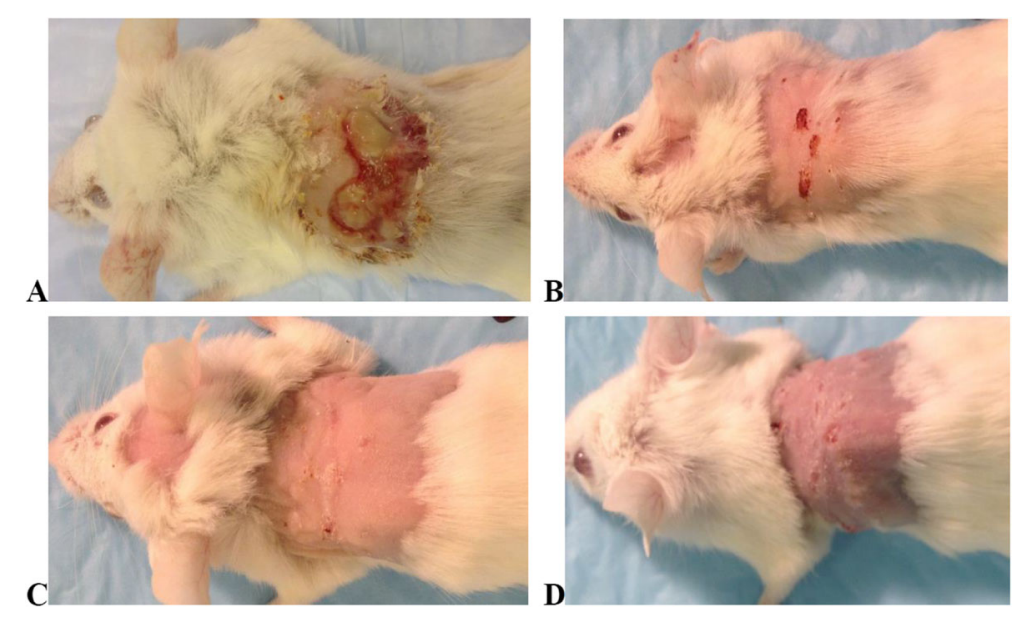

Fig. 2 Representative images diabetic mouse wound at day 10 of infection: A infected saline-treated, showing lack of healing and expansion of wounds; B uninfected phage-treated, C infected phage-treated, and D infected vancomycin-treated. Wounds in B, C, and D groups showed similar complete healing 


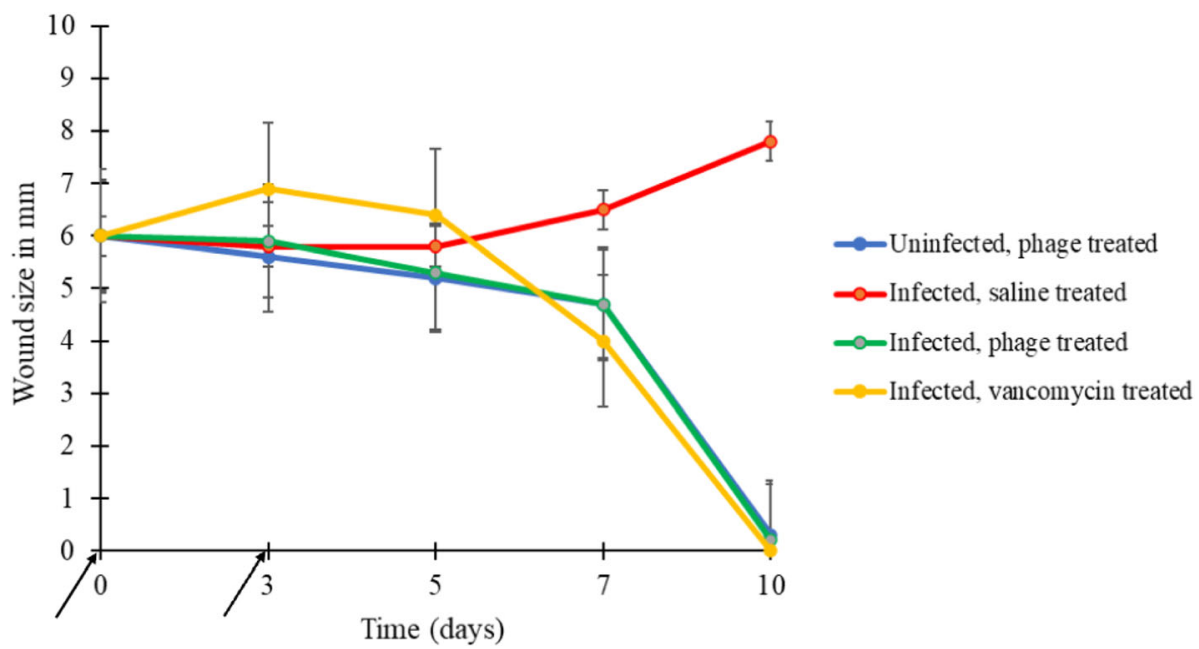

Fig. 3 Effect of phage AB-SA01 on wound healing. The arrows on the horizontal axis indicate the infection date (first arrow, day 0) and treatment started date (second arrow, day 3). No healing was seen in infected saline-treated mice. In contrast, complete wound healing was seen in uninfected phage-treated wounds, and infected wounds treated with phage, and in the control group with infected wounds and vancomycin treatment

no apparent adverse effects in mice in the absence or presence of its bacterial host.

\section{Clinical and postmortem assessment}

Hunching, ruffled coat, lethargy, cold to touch, crinkling of skin, sunken eyes, and rapid or labored breathing were criteria used to check the health of mice. No mice manifested clinical signs of systemic infection during the infection and treatment periods. Non-healing wounds with purulent exudate, discolored granulation tissue, and foul odor were noted in all infected mice before treatment for all treatment groups, and the entire period of the experiment in the untreated groups. No gross pathological lesion was observed in any of the visceral organs examined during post-mortem investigation.

\section{Discussion}

An inbred, chemically induced diabetic mouse (Balb/c) model was employed to assess the efficacy of AB-SA01 to treat MDR $S$. aureus infection in diabetic mice wounds. Multiple low doses of STZ resulted in a high proportion of diabetic mice, as reported [25, 26]. Skin wound healing in rodents involves skin contraction, a healing mechanism not seen in human wound healing, which occurs by secondary intention, granulation, and re-epithelialization [27, 28]. We employed a splint wound model to better mimic human skin wounds by avoiding the contraction type of mice wound healing, as described recently [27, 29]. We found that the silicone splints remained fixed on the mice's skin until the end of the experiment.

Treatment of staphylococcal diabetic foot infections with antibiotics is becoming increasingly difficult because of the widespread presence of antibioticresistant $S$. aureus strains [10, 11, 30]. Previous reports have shown the potential of phages as an alternative or adjunctive therapy to treating bacterial infections in an animal model [31, 32], but information regarding the treatment of human DFUs caused by MDR S. aureus using a phage cocktail topically is limited. In this study, the therapeutic potential of AB-SA01 was tested on diabetic mice to treat wounds infected with an $S$. aureus clinical isolate resistant to multiple antibiotics, including those most commonly used to treat staphylococcal infections such as oxacillin, clindamycin, and trimethoprimsulfamethoxazole. Inflicted wounds were infected the same day that the wounding occurred. After a week of treatment, AB-SA01 reduced bacterial loads to minimal levels while the control mice were still infected with a high bacterial load. A statistically significant $(p<0.001)$ viable bacterial load decrease was observed on day 5 and it continued to decrease throughout the infection period in AB-SA01-treated mice. The infection process, in terms of bacterial load and wound size, in phage- and vancomycin-treated groups was controlled well $(p<$ 0.001) compared to untreated control mice.

The bacterial load in the vancomycin-treated group continued to decrease at a similar trajectory to the phage-treated group during the treatment period but remained constant from the day treatment was completed. The bacterial load reduction at the end of the experiment in vancomycin-treated mice was not as great and was significantly different $(p<0.05)$ from that in phage-treated mice. The continued bacterial load reduction in phage-treated mice after the treatment was stopped demonstrates an advantage of phages over 
antibiotic treatment, because phages replicate in the presence of their bacterial host [33, 34]. Of the eight infected phage-treated mice, $S$. aureus had been eradicated from the wounds of five mice by the end of the experiment. In the three remaining mice with detectable $S$. aureus, bacterial load was minimal compared to that in saline-treated mice. In contrast to phage-treated mice, at the end of the experiment, S. aureus was still detected from all the vancomycin-treated mice with mean bacterial load of $4.81 \log _{10}$ (CFU/swab). Four of the six vancomycin-treated mice had a residual bacterial burden of $\geq 5.86 \log _{10}$ (CFU/swab) at the end of the experiment.

From these observations, we conclude that AB-SA01 treatment could result in superior or equivalent efficacy to vancomycin, the usual first-line antimicrobial used to treat severe methicillin-resistant $S$. aureus infections. The data suggest that phages may be useful as an alternative therapy to antibiotics in this setting because they: a) may be used topically, b) show promising preliminary efficacy with a small number of treatments, shown here with three topical administrations, which is more compatible with standard wound care, c) show no local inflammatory reaction, d) may continue to work for an extended period post-administration, and e) have fewer documented adverse effects as compared to antibiotics such as vancomycin [35, 36]. Future controlled experiments are needed to determine the synergy of phage and antibiotic treatment.

Some reports suggest the effects of topical application of phages might be enhanced by simultaneous appropriate wound debridement [32, 37]. The effectiveness of this phage treatment that employed gentle debridement, topical application of a phage cocktail, and covering with light dressings such as gauze and Opsite, may represent a method for developing better diabetic wound care.

The use of well-developed phage cocktails (instead of single phage) not only broadens the spectrum of activity of therapeutic phage formulations but also reduces the likelihood of development of phage resistant bacteria $[38,39]$. This could be because component phages complement each other, possess different infection mechanisms, and may recognize different receptors [40]. The three phage components in AB-SA01 were shown to broaden the spectrum of activity and complement each other [24].

The topical administration of AB-SA01 exhibited an effect similar to that observed with vancomycin in hastening infected wound healing. The decrease in wound size also correlated well with the decrease in bacterial load in each of the treatment groups, confirming that bacterial counts differences measured in swab samples reflected the bacteria load in vivo. Wound size measurement showed a significant difference $(\mathrm{p}<0.001)$ between the treatment and control groups. More than $85 \%$ of uninfected phage-treated, infected phage-treated, and infected vancomycin-treated mice wounds combined were completely closed, and hair re-growth was observed on some of the wounds. No significant difference $(p>0.05)$ was observed in wound closure between the three treatment groups.

AB-SA01 was well tolerated by the mice, as shown by the lack of clinical abnormalities such as changes in the well-being of mice or evidence of anaphylactic reactions due to harmful response to phages. This finding is in line with reports on the safety of phage therapy $[35,36$, 41-43]. Adverse effects due to rapid bacterial lysis such as bacterial rebound and circulatory shock due to the release of large quantities of toxins when considerable numbers of bacteria are lysed [42], or anti-inflammatory responses $[44,45]$ were not observed. The absence of adverse effect was expected as the AB-SA01 products used in this experiment is a well-characterized phage cocktail, produced under cGMP standards, and which has been approved by the U.S. Food and Drug Administration (FDA) and Australia's Therapeutic Goods Administration (TGA) for use in clinical phase I trials and single-patient emergency treatment $[24,43]$.

\section{Conclusion}

The treatment of diabetic wound infections caused by MDR S. aureus using topical application of phage cocktail AB-SA01 is effective, as shown by bacterial load reduction and wound closure. The findings of this study show that phages represent a potentially effective topical treatment for diabetic ulcers infected with antibioticresistant pathogens.

\section{Methods}

\section{Bacterial culture}

MDR S. aureus isolate 63-2498 (MDR SA63-2498) collected from an Adelaide DFU patient, was identified using matrix-assisted laser desorption/ionization timeof-flight mass spectrometry (MALDI TOF MS) (Bruker Daltonics Biotyper, Bruker Pty. Ltd., Victoria, Australia). MDR SA63-2498 was tested using a VITEK 2 system (bioMérieux, New South Wales, Australia) and demonstrated resistance to multiple antibiotics, including benzylpenicillin, oxacillin, ciprofloxacin, erythromycin, and clindamycin and susceptibility to vancomycin. MDR SA63-2498 was susceptible to lysis by AB-SA01 and each of its component phages in planktonic and biofilm states during the pilot study (data not shown). A single colony of MDR SA63-2498 grown on a mannitol salt agar (MSA) (Thermo Fisher Scientific, South Australia, Australia) plate was taken and grown in $3 \mathrm{ml}$ trypticase soy broth (TSB) (Thermo Fisher Scientific, South Australia, Australia) overnight with shaking at $160 \mathrm{rpm}$ and $37^{\circ} \mathrm{C}$. One milliliter from the TSB overnight broth 
culture was adjusted to an optical density (OD) of 0.7 at $\mathrm{OD}_{600}$ using a SP-830+ Metertech spectrophotometer (Adelab, South Australia, Australia) that corresponds to $2.3 \log _{10}(\mathrm{CFU} / \mathrm{ml})$ through dilution with sterile physiological saline. The adjusted broth culture was centrifuged at $3000 \mathrm{rpm}$, and pelleted cells were washed twice and resuspended with $1 \mathrm{ml}$ saline. This suspension was used for inoculation into mice's wounds.

\section{Phage cocktail}

Phage cocktail AB-SA01 was provided by AmpliPhi Biosciences Corporation (now Armata Pharmaceuticals, Inc.). It is a combination of three Myoviridae phages designated J-Sa36, Sa83, and Sa87. The mean titer was $9.3 \log _{10}$ (PFU/ml) for J-Sa36 and Sa83, $9.0 \log _{10}$ (PFU/ $\mathrm{ml})$ for Sa87, and $9.1 \log _{10}(\mathrm{PFU} / \mathrm{ml})$ for AB-SA01 on $S$. aureus laboratory strains RN4220 and SA6538 using plaque assay [24].

\section{Laboratory animal management}

Female Balb/c mice were obtained from the Animal Resources Centre, Perth, Western Australia. All experiments were approved by the Animal Welfare Committee, Flinders University/Southern Adelaide Local Health Network, and carried out in compliance with the ARRIVE guidelines [46]. Mice were kept at the College of Medicine and Public Health Animal Facility, Flinders University, at $22 \pm 3{ }^{\circ} \mathrm{C}$ and $55 \pm 5 \%$ humidity under a 12:12 h light-dark cycle in Tecniplast GM500 Mouse IVC Greenline cages (Tecniplast Australia Pty Ltd., New South Wales, Australia) using corncob bedding. Mice were kept in specific pathogen-free conditions. Mice were provided water and meat-free rodent maintenance diet (Glen Forrest Stockfeeders, Western Australia, Australia) ad libitum. The research was conducted consistent with the Australian Code for the Care and Use of Animals for Scientific Purposes, 8th edition, 2013.

Mice were weighed 2-3 times each week and monitored for hunching, ruffled coat, lethargy, cold to touch, crinkling of skin, sunken eyes, and rapid or labored breathing at least once daily. Mice that showed over 15\% weight loss or were critically ill were euthanized. Vancomycin (Sigma-Aldrich Corporation, New South Wales, Australia) was assessed for possible toxicity on six mice in a separate pilot study at $150 \mathrm{mg} / \mathrm{kg}$ dose rate, twice daily IP, for five consecutive days as described [47]; these mice did not display any apparent adverse reaction. At the end of the experiment, mice were euthanized using $3 \%$ isoflurane, followed by cervical dislocation. Postmortem examination of the external surfaces and visceral organs was conducted following an established procedure [48].

\section{Induction of diabetes in mice}

The diabetes mouse model was used to mimic the human diabetes setting, the source of the experimental bacteria isolates. A total of 48 female 8 -week-old Balb/c mice, housed in groups of 5, received streptozotocin (STZ) (Sigma-Aldrich Corporation, New South Wales, Australia) following an established protocol [26]. Balb/c mice are among the least susceptible to STZ toxicity because of their relatively high pancreatic $\beta$-cell mass due to their large number of islets [49]. Female mice are relatively resistant to the glucotoxicity of STZ compared to males because sex steroids protect them from $\beta$-cells injury [50]. Besides, STZ-diabetic nephropathy is more pronounced in male mice compared to females [49]. STZ is a naturally occurring alkylating antineoplastic agent that is toxic to pancreatic insulin-producing cells. It is used to treat pancreas islet cell carcinoma and to induce diabetes mellitus in laboratory rodents [25].

After $4 \mathrm{~h}$ of fasting, each mouse received an IP injection of $50 \mathrm{mg} / \mathrm{kg}$ freshly dissolved STZ in $0.05 \mathrm{M}$ citrate buffer $\mathrm{pH} 4.5$ once daily for five consecutive days. Nonfasting blood glucose levels (BGL) were checked every $2-3$ days by tail vein bleeding after applying 3\% lidocaine/prilocaine anesthetic cream. BGLs were measured using an Accu-Chek Performa (Roche Diabetes Care Australia, New South Wales, Australia) blood glucose meter. Mice with non-fasting $\mathrm{BGL}<13.9$, between 13.9 and 22.2 , and $\geq 22.2 \mathrm{mmol} / \mathrm{L}$ on at least two different days were categorized as normal glycaemic, moderate hyperglycaemic, or severe hyperglycaemic status, respectively, as described earlier [51]. Mice were treated with 1.0 IU NovoMix 30 (Novo Nordisk, New South Wales, Australia) insulin subcutaneously daily, from the second week of diabetes manifestation, to ameliorate the hyperglycaemic effects of diabetes and maintain body weight [52].

\section{Excisional wound infliction}

Diabetic mice were provided with lemon-flavored paracetamol in drinking water at $1.34 \mathrm{mg} / \mathrm{ml} 3$ days prior to wound infliction and for the entire experimental period. An established rodent wound infection model [29] was used. Mice were anaesthetized using 3\% isoflurane inhalation and maintained on $1.5 \%$ during surgery. Hair was removed on the dorsal skin using electric clippers and depilatory cream, and skin sterilized using $70 \%$ ethanol. Mice were given a single $0.05 \mathrm{mg} / \mathrm{kg}$ buprenorphine injection subcutaneously before the incisions. Hydrating eye drops were applied during anesthesia.

A skin wound extending through the Panniculus carnosus muscle was inflicted using a $6 \mathrm{~mm}$ sterile biopsy punch and fine scissors. The bilateral wounds were at $10 \mathrm{~mm}$ either side of the midline and $30 \mathrm{~mm}$ from the base of the skull. Swab samples were collected from each 
wound to assess for existing S. aureus. A sterile $1 \mathrm{~mm}$ thick silicone splint with a $7 \mathrm{~mm}$ diameter circular hole at the center was applied over the wound and sutured onto the skin concentric with the wound using 5-0 nylon suture. Cyanoacrylate glue was used to fix the silicone splint to the skin before suturing. The silicon splints were removed at the end of the experiment.

\section{Wound infection and treatment}

Mice were randomly assigned into $S$. aureus-inoculated phage-treated $(n=8), S$. aureus-inoculated vancomycintreated $(n=6), S$. aureus-inoculated saline-treated $(n=$ $7)$, and saline-inoculated phage-treated $(n=8)$ groups. $S$. aureus-inoculated mice were infected with $50 \mu \mathrm{l}$ suspension containing $6.7 \log _{10}$ (CFU) of MDR SA63-2498 prepared as above. Mice in the saline-inoculated group received $50 \mu \mathrm{l}$ of saline. Suspensions were applied directly into each wound, overlaid with gauze, and covered with Opsite sterile transparent wound dressing, which adhered to the silicon splint and retained in place the gauze dressing. Post-infection, each mouse was kept in a single housing system. On days 3,5 , and 7 postinfection, the Opsite was removed, and swab samples were taken. Swab samples were taken by scrubbing the surface of each wound by rotating three times clockwise with enough pressure to produce a small amount of exudate and inserted into a separate tube of $1 \mathrm{ml}$ TSB. The tube was vortexed (with the swab inside), to distribute the bacteria in the TSB solution evenly, for $5 \mathrm{~s}$, and a $100 \mu \mathrm{l}$ aliquot was used for 10 -fold serial dilutions. Swab samples were kept at $+4{ }^{\circ} \mathrm{C}$ and processed for the bacterial count within $4 \mathrm{~h}$ of collection.

Treatments were administered after sample collection commencing on day 3 . Gauze patches $(10 \times 10 \mathrm{~mm})$ soaked with $70 \mu \mathrm{l} \mathrm{AB}-\mathrm{SA} 01$, equivalent to $7.9 \log _{10} \mathrm{PFU}$, or $70 \mu \mathrm{l}$ saline solutions for control and vancomycintreated mice, were applied to wounds and covered with Opsite, on days 3, 5, and 7 post-infection. Vancomycintreated mice received $150 \mathrm{mg} / \mathrm{kg}$ vancomycin IP twice daily for five consecutive days, as described [47]. Topical vancomycin was not an option because its best topical dose is unknown, it has poor tissue penetration, and could contribute to vancomycin resistance [30, 53]. Both wounds of a mouse received the same infection and treatment.

\section{Assessment of treatment effect on bacterial load and wound healing}

Wound size was measured in duplicate from multiple directions using a digital Vernier caliper by tracing the leading edge of epithelium within the wound [54]. The wound size on the excision day was defined as the original wound size. One hundred microliters of 10-fold serially diluted swab sample suspensions were mixed with $3 \mathrm{ml}$ trypticase soy soft agar containing $0.65 \%$ bacteriological agar for even distribution of the bacteria [55] and cultured on MSA to assess the bacterial load. After $24 \mathrm{~h}$ of incubation at $37^{\circ} \mathrm{C}$ aerobically, colony count was performed on plates with 30-300 colonies as recommended [56]. The bacterial population was calculated using the formula $B=N / d$ where $B=$ number of bacteria, $\mathrm{N}=$ average number of colonies, and $\mathrm{d}=$ dilution factor.

\section{Data management and statistical analysis}

Data were double entered, encoded, and stored using Microsoft Excel Spreadsheet. STATA (version 16) software was used for statistical analysis. Data are reported in terms of mean \pm standard error. CFU data are expressed as logarithm-transformed values $\left(\log _{10}\right.$ (CFU $/ \mathrm{ml})$ ) over time. A comparison of experimental groups was performed using a one-way analysis of variance (two-tailed) or paired 't-test'. A $p<0.05$ value was considered statistically significant.

\section{Abbreviations}

BGL: Blood glucose level; CFU: Colony-forming units; CGMP: Current good manufacturing practice; DFU: Diabetic foot ulcer; FDA: Food and Drug Administration (FDA); IP: Intraperitoneal; MALDI TOF MS: Matrix-assisted laser desorption/ionization time-of-flight mass spectrometry; MDR: Multidrugresistant; MRSA: Methicillin-resistant S. aureus; MSA: Mannitol salt agar; OD: Optical density; PFU: Plaque forming unit; RPM: Revolutions per minute; S. aureus: Staphylococcus aureus; STZ: Streptozotocin; TGA: Therapeutic Goods Administration; TSB: Trypticase soy broth (TSB); US: United States

\section{Acknowledgments}

We are grateful to A/Prof. Allison Cowin, Dr. Christina Bursill, and Dr. Xanthe Strudwick for advice on diabetic mouse models of skin wounds. AmpliPhi Bioscience Corporation (now Armata Pharmaceutical) is greatly

acknowledged for generously providing the phages.

\section{Authors' contributions}

LGK participated in the conception of the research idea and designing the methodology, performed laboratory and animal experiment works, data collection, and prepared the manuscript. PS and JGM participated in the conception of the research idea and design of the methodology. PS and LV participated in animal experiment work. RW and LGK performed data analysis. MSW, SM, LV, RW, JGM, RF, and PS participated in data collection and edited the manuscript. All researchers approved the final manuscript.

\section{Funding}

Diabetes Australia Research Program granted the research fund necessary to cover costs related to experimental animals and laboratory supplies purchase, and experimental house rent to the study. Diabetes Australia Research Program had no role in research concept development, experimental design, and manuscript preparation.

\section{Availability of data and materials}

The datasets used and/or analyzed during the current study are available from the corresponding author on reasonable request.

\section{Ethics approval and consent to participate}

Ethical clearance for the infection and treatment on the mice was obtained from the Animal Welfare Committee, Flinders University/Southern Adelaide Local Health Network. The experiment was carried out in compliance with the ARRIVE guidelines. 


\section{Competing interests}

S.M was an AmpliPhi Biosciences employee at the time of performing the experiments and contributed to the scientific discussion. All other authors declare no conflict of interest.

\section{Author details}

'College of Science and Engineering, Flinders University, Adelaide, South Australia, Australia. ${ }^{2}$ St Paul's Hospital Millennium Medical College, Addis Ababa, Ethiopia. Infectious Diseases Unit, The Queen Elizabeth Hospital, Woodville, South Australia, Australia. ${ }^{4}$ Faculty of Medicine, University of Adelaide, Adelaide, South Australia, Australia. ${ }^{5}$ AmpliPhi Biosciences Corporation, Sydney, New South Wales, Australia. ${ }^{6}$ Research Development and Support, Flinders University, Adelaide, South Australia, Australia. ${ }^{7}$ College of Medicine and Public Health, Flinders University, Adelaide, South Australia, Australia. ${ }^{8}$ Discipline of Surgery, The University of Adelaide, Adelaide, South Australia, Australia.

Received: 3 April 2020 Accepted: 1 July 2020

Published online: 09 July 2020

\section{References}

1. Thurber EG, Kisuule F, Humbyrd C, Townsend J. Inpatient Management of Diabetic Foot Infections: a review of the guidelines for hospitalists. J Hosp Med. 2017;12(12):994-1000

2. Armstrong DG, Boulton AJM, Bus SA. Diabetic foot ulcers and their recurrence. N Engl J Med. 2017:376(24):2367-75.

3. Lavery LA, Armstrong DG, Murdoch DP, Peters EJ, Lipsky BA. Validation of the Infectious Diseases Society of America's diabetic foot infection classification system. Clin Infect Dis. 2007;44(4):562-5.

4. Robbins JM, Strauss G, Aron D, Long J, Kuba J, Kaplan Y. Mortality rates and diabetic foot ulcers: is it time to communicate mortality risk to patients with diabetic foot ulceration? J Am Podiatr Med Assoc. 2008;98(6):489-93.

5. Lipsky BA, Berendt AR, Deery HG, Embil JM, Joseph WS, Karchmer AW LeFrock JL, Lew DP, Mader JT, Norden C. Diagnosis and treatment of diabetic foot infections. Clin Infect Dis. 2004;39(7):885-910.

6. Richard J-L, Sotto A, Lavigne J-P. New insights in diabetic foot infection. World J Diabetes. 2011:2(2):24.

7. Rice JB, Desai U, Cummings AKG, Birnbaum HG, Skornicki M, Parsons NB: Burden of Diabetic foot Ulcers for Medicare and Private Insurers. Diabetes Care 2013:DC_132176

8. Kerr M, Barron E, Chadwick P, Evans T, Kong WM, Rayman G, Sutton-Smith M, Todd G, Young B, Jeffcoate WJ. The cost of diabetic foot ulcers and amputations to the National Health Service in England. Diabet Med. 2019; 36(8):995-1002.

9. Messad N, Prajsnar TK, Lina G, O'Callaghan D, Foster SJ, Renshaw SA, Skaar EP, Bes M, Dunyach-Remy C, Vandenesch F, et al. Existence of a colonizing Staphylococcus aureus strain isolated in diabetic foot ulcers. Diabetes. 2015; 64(8):2991-5.

10. Reveles KR, Duhon BM, Moore RJ, Hand EO, Howell CK. Epidemiology of methicillin-resistant Staphylococcus aureus diabetic foot infections in a large academic hospital: implications for antimicrobial stewardship. PLoS One. 2016;11(8):e0161658.

11. Commons RJ, Robinson CH, Gawler D, Davis JS, Price RN. High burden of diabetic foot infections in the top end of Australia: an emerging health crisis (DEFINE study). Diabetes Res Clin Pract. 2015;110(2):147-57.

12. Uçkay I, Aragón-Sánchez J, Lew D, Lipsky BA. Diabetic foot infections: what have we learned in the last 30 years? Int J Infect Dis. 2015;40:81-91.

13. Young R. Bacteriophage lysis: mechanism and regulation. Microbiol Rev. 1992;56(3):430-81.

14. Summers WC. The strange history of phage therapy. Bacteriophage. 2012; 2(2):130-3.

15. Wittebole X, De Roock S, Opal SM. A historical overview of bacteriophage therapy as an alternative to antibiotics for the treatment of bacterial pathogens. Virulence. 2014;5(1):226-35.

16. Shkoporov AN, Clooney AG, Sutton TD, Ryan FJ, Daly KM, Nolan JA, McDonnell SA, Khokhlova EV, Draper LA, Forde A: The human gut virome is highly diverse, stable, and individual specific. Cell host \& microbe 2019, 26(4): 527-541. e525.

17. Edwards R, Vega A, Norman H, Ohaeri MC, Levi K, Dinsdale E, Cinek O, Aziz R, McNair K, Barr J: Global phylogeography and ancient evolution of the widespread human gut virus crAssphage. bioRxiv 2019:527796.
18. Donlan RM. Preventing biofilms of clinically relevant organisms using bacteriophage. Trends Microbiol. 2009;17(2):66-72.

19. Brüssow $\mathrm{H}$. What is needed for phage therapy to become a reality in Western medicine? Virology. 2012;434(2):138-42.

20. Pirnay JP, De Vos D, Verbeken G, Merabishvili M, Chanishvili N, Vaneechoutte M, Zizi M, Laire G, Lavigne R, Huys I, et al. The phage therapy paradigm: Prt-a -porter or Sur-mesure? Pharm Res. 2011;28(4):934-7.

21. Reyes A, Semenkovich NP, Whiteson K, Rohwer F, Gordon Jl. Going viral: next-generation sequencing applied to phage populations in the human gut. Nat Rev Microbiol. 2012;10(9):607-17.

22. Sharma M. Lytic bacteriophages: potential interventions against enteric bacterial pathogens on produce. Bacteriophage. 2013;3(2):e25518.

23. Fish R, Kutter E, Wheat G, Blasdel B, Kutateladze M, Kuhl S. Bacteriophage treatment of intransigent diabetic toe ulcers: a case series. J Wound Care. 2016:25(7):S27-33.

24. Lehman SM, Mearns G, Rankin D, Cole RA, Smrekar F, Branston SD, Morales $\mathrm{S}$ : Design and Preclinical Development of a Phage Product for the Treatment of Antibiotic-Resistant Staphylococcus aureus Infections. Viruses 2019, 11(1).

25. Deeds MC, Anderson JM, Armstrong AS, Gastineau DA, Hiddinga HJ, Jahangir A, Eberhardt NL, Kudva YC. Single dose streptozotocin-induced diabetes: considerations for study design in islet transplantation models. Lab Anim. 2011:45(3):131-40.

26. Ito M, Kondo Y, Nakatani A, Hayashi K, Naruse A. Characterization of low dose streptozotocin-induced progressive diabetes in mice. Environ Toxicol Pharmacol. 2001;9(3):71-8.

27. Fukui T, Kawaguchi AT, Takekoshi S, Miyasaka M, Sumiyoshi H, Tanaka R. Liposome-encapsulated hemoglobin accelerates skin wound healing in diabetic dB/dB mice. Artif Organs. 2017;41(4):319-26.

28. Park SA, Raghunathan VK, Shah NM, Teixeira L, Motta MJ, Covert J, Dubielzig R, Schurr M, Isseroff RR, Abbott NL. PDGF-BB does not accelerate healing in diabetic mice with splinted skin wounds. PLoS One. 2014;9(8):e104447.

29. Dunn L, Prosser HC, Tan JT. Vanags LZ, Ng MK. Bursill CAJJoveJ: Murine model of wound healing. 2013;75.

30. Lipsky BA, Hoey C. Topical antimicrobial therapy for treating chronic wounds. Clin Infect Dis. 2009:49(10):1541-9.

31. McVay CS, Velasquez M, Fralick JA. Phage therapy of Pseudomonas aeruginosa infection in a mouse burn wound model. Antimicrob Agents Chemother. 2007;51(6):1934-8.

32. Seth AK, Geringer MR, Nguyen KT, Agnew SP, Dumanian Z, Galiano RD, Leung KP, Mustoe TA, Hong SJ. Bacteriophage therapy for Staphylococcus aureus biofilm-infected wounds: a new approach to chronic wound care. Plast Reconstr Surg. 2013;131(2):225-34.

33. Payne RJ, Phil D, Jansen VA. Phage therapy: the peculiar kinetics of selfreplicating pharmaceuticals. Clin Pharmacol Ther. 2000;68(3):225-30.

34. Fu W, Forster T, Mayer $\mathrm{O}$, Curtin JJ, Lehman SM, Donlan RM. Bacteriophage cocktail for the prevention of biofilm formation by Pseudomonas aeruginosa on catheters in an in vitro model system. Antimicrob Agents Chemother. 2010;54(1):397-404.

35. Speck P, Smithyman A: Safety and efficacy of phage therapy via the intravenous route. FEMS Microbiol Lett 2016, 363(3).

36. Rhoads D, Wolcott R, Kuskowski M, Wolcott B, Ward L, Sulakvelidze A. Bacteriophage therapy of venous leg ulcers in humans: results of a phase I safety trial. J Wound Care. 2009;18(6):237-43.

37. Chhibber S, Kaur T, Sandeep K. Co-therapy using Iytic bacteriophage and linezolid: effective treatment in eliminating methicillin resistant Staphylococcus aureus (MRSA) from diabetic foot infections. PLoS One. 2013;8(2):e56022.

38. Chan BK, Abedon ST, Loc-Carrillo C. Phage cocktails and the future of phage therapy. Future Microbiol. 2013;8(6):769-83.

39. Cairns BJ, Payne RJ. Bacteriophage therapy and the mutant selection window. Antimicrob Agents Chemother. 2008;52(12):4344-50.

40. Gu J, Liu X, Li Y, Han W, Lei L, Yang Y, Zhao H, Gao Y, Song J, Lu R. A method for generation phage cocktail with great therapeutic potential. PLoS One. 2012;7(3):e31698.

41. Drilling AJ, Ooi ML, Miljkovic D, James C, Speck P, Vreugde S, Clark J, Wormald PJ. Long-term safety of topical bacteriophage application to the frontal sinus region. Front Cell Infect Microbiol. 2017:7:49.

42. Capparelli R, Parlato M, Borriello G, Salvatore P, lannelli D. Experimental phage therapy against Staphylococcus aureus in mice. Antimicrob Agents Chemother. 2007;51(8):2765-73. 
43. Fabijan AP, Lin RC, Ho J, Maddocks S, Zakour NLB, Iredell JR. Safety of bacteriophage therapy in severe Staphylococcus aureus infection. Nat Microbiol. 2020;5(3):465-72.

44. Sweere JM, Van Belleghem JD, Ishak H, Bach MS, Popescu M, Sunkari V, Kaber G, Manasherob R, Suh GA, Cao X: Bacteriophage trigger antiviral immunity and prevent clearance of bacterial infection. Science 2019 363(6434):eaat9691.

45. Van Belleghem JD, Clement F, Merabishvili M, Lavigne R, Vaneechoutte M. Pro-and anti-inflammatory responses of peripheral blood mononuclear cells induced by Staphylococcus aureus and Pseudomonas aeruginosa phages. Sci Rep. 2017;7(1):1-13.

46. Kilkenny C, Browne WJ, Cuthill IC. Emerson M. Altman DGJPb: Improving bioscience research reporting: the ARRIVE guidelines for reporting animal research. 2010;8(6):e1000412.

47. Gibson GW, Kreuser SC, Riley JM, Rosebury-Smith WS, Courtney CL, Juneau PL, Hollembaek JM, Zhu T, Huband MD, Brammer DW. Development of a mouse model of induced Staphylococcus aureus infective endocarditis. Comparative medicine. 2007;57(6):563-9.

48. Parkinson CM, O'Brien A, Albers TM, Simon MA, Clifford CB, PritchettCorning KR. Diagnostic necropsy and selected tissue and sample collection in rats and mice. J Vis Exp. 2011;54.

49. Hayashi K, Kojima R, Ito M. Strain differences in the diabetogenic activity of streptozotocin in mice. Biol Pharm Bull. 2006;29(6):1110-9.

50. Le May C, Chu K, Hu M, Ortega CS, Simpson ER, Korach KS, Tsai M-J, Mauvais-Jarvis F. Estrogens protect pancreatic $\beta$-cells from apoptosis and prevent insulin-deficient diabetes mellitus in mice. Proc Natl Acad Sci. 2006; 103(24):9232-7.

51. Grant CW, Duclos SK, Moran-Paul CM, Yahalom B, Tirabassi RS, ArreazaRubin G, Spain LM, Guberski DL. Development of standardized insulin treatment protocols for spontaneous rodent models of type 1 diabetes. Comparative medicine. 2012;62(5):381-90.

52. Guo A, Daniels NA, Thuma J, McCall KD, Malgor R, Schwartz FL. Diet is critical for prolonged glycemic control after short-term insulin treatment in high-fat diet-induced type 2 diabetic male mice. PLoS One. 2015;10(1): e0117556.

53. Kollef MH. Limitations of vancomycin in the management of resistant staphylococcal infections. Clin Infect Dis. 2007:45(Suppl 3):S191-5.

54. Shah A, Wollak C, Shah J. Wound measurement techniques: comparing the use of ruler method, 2D imaging and 3D scanner. Journal of the American College of Clinical Wound Specialists. 2013;5(3):52-7.

55. Alves DR, Gaudion A, Bean J, Esteban PP, Arnot T, Harper D, Kot W, Hansen $\mathrm{LH}$, Enright M, Jenkins ATA. Combined use of bacteriophage $\mathrm{K}$ and a novel bacteriophage to reduce Staphylococcus aureus biofilm formation. Appl Environ Microbiol. 2014:80(21):6694-703.

56. O'Toole GA. Classic spotlight: plate counting you can count on. J Bacteriol. 2016;198(23):3127.

\section{Publisher's Note}

Springer Nature remains neutral with regard to jurisdictional claims in published maps and institutional affiliations.

Ready to submit your research? Choose BMC and benefit from:

- fast, convenient online submission

- thorough peer review by experienced researchers in your field

- rapid publication on acceptance

- support for research data, including large and complex data types

- gold Open Access which fosters wider collaboration and increased citations

- maximum visibility for your research: over $100 \mathrm{M}$ website views per year

At $\mathrm{BMC}$, research is always in progress.

Learn more biomedcentral.com/submissions 